\title{
Implementasi Pembelajaran Pendidikan Agama Islam dalam Keluarga Santri
}

\author{
Didik Toha
}

\author{
PAI Universitas Alma Ata
}

\section{Lathifatul Izzah}

PAI Universitas Alama Ata, lathifatul.izzah@almaata.ac.id

\begin{abstract}
This paper aims to describe and analyze the process and implications of the implementation of Islamic religious education learning in santri families in Wonolelo village, Pleret district, Bantul district. Qualitative methods with the type of case study research are used to reveal these expectations. Data collection was carried out by observation, interviews, and documentation. The collected data were analyzed by analytical induction.

The process of implementing Islamic religious education learning in the santri family can be carried out through planning, implementation and evaluation. The third process can be successful, influenced by various factors. Among them are materials, methods, environment, technology, and cooperation or cohesiveness between family members, especially both parents. Finally, family education can have an impact or have implications for the character of family members, especially children as themselves, relating to Allah, the Lord of the Universe, God's fellow creatures.
\end{abstract}

Keywords: Implimentation, learning, Islamic religious education, santri families

\begin{abstract}
Abstrak
Tulisan ini bertujuan untuk mendeskripsikan dan menganalisis proses dan implikasi implementasi pembelajaran pendidikan agama Islam dalam keluarga santri di desa Wonolelo kecamatan Pleret kabupaten Bantul. Metode kualitatif dengan jenis penelitian studi kasus dipakai untuk mengungkap harapan tersebut. Pengumpulan data dilakukan dengan observasi, wawancara, dan dokumentasi. Data-data yang terkumpul dianalisis dengan induksi analitis.

Proses implementasi pembelajaran pendidikan Agama Islam dalam keluarga santri dapat dilakukan melalui perencanaan, pelaksanaan dan evaluasi. Proses ketiganya dapat berhasil dengan baik dipengaruhi oleh berbagai macam faktor. Diantaranya adalah materi, metode, lingkungan, teknologi, dan kerjasama atau kekompakan antar anggota keluarga, terutama kedua orang tua. Akhirnya pendidikan keluarga dapat berdampak atau berimplikasi pada karakter anggota keluarga, terutama anak selaku menjadi diri sendiri, berhubungan pada Allah Tuhan Alam Semesta, makhluk sesama makhluk Allah.
\end{abstract}

Kata kunci: Implementasi, Pembelajaran, Pendidikan Agama Islam, Keluarga Santri. 


\section{PENDAHULUAN}

Empat pusat pendidikan, keluarga, sekolah, masyarakat, dan tempat ibadah memiliki peran dan fungsi masing-masing. ${ }^{1}$ Keluarga menjadi lembaga pendidikan pertama dan utama. Dalam keluarga, anak pertama kali mendapatkan pendidikan dan bimbingan. Pada umumnya kehidupan anak ada di dalam keluarga, lebih-lebih pada saat pandemi COVID-19 (Corona Virus Disease 2019). Pendidikan yang paling banyak diterima oleh anak adalah pendidikan keluarga. ${ }^{2}$ Sebelum lembaga pendidikan formal atau sekolah lahir, keluarga sudah menjadi lembaga pelatak dasar pendidikan. Dari keluarga, anak mampu mempelajari banyak hal, mulai dari cara berinteraksi, menyatakan keinginan dan perasaan pada orang lain, bertutur kata, bersikap, berperilaku, sampai pada bagaimana menganut niai-nilai tertentu sebagai prinsip hidupnya, misalnya nilai keilahian, kesetiaan, kelembutan (anti-kekerasan), kasih sayang, keseimbangan, memahami, menghormati, menghargai, perdamaian, dan keadilan. ${ }^{3}$

Keluarga bertanggung jawab untuk menanamkan nilai-nilai agama. Sekalipun orang tua telah memasukkan anak ke sekolah formal atau non-formal untuk mendapatkan pendidikan agama, tetapi kewajiban memberikan pendidikan agama Islam tetap berada di tangan orang tua. Orang tua, utamanya ibu bisa dibilang berperan total dalam pendidikan anak dalam kesehariannya. Mereka menggunakan hand, head, dan heart dalam pendidikan agar anak-anaknya berperilaku baik sebagaimana diajarkan oleh Rasulullah SAW. ${ }^{4}$

${ }^{1}$ Imam Machalli, "Pendekatan IntegratifInterkonektif dalam Kajian Kebijakan dan Manajemen Pendidikan Islam", dalam M. Amin Abdullah, dkk. Implementasi Pendekatan Integratif-Interkonektif dalam Kajian Pendidikan Islam, (Yogyakarta: Pascasarjana UIN Sunan Kalijaga, 2014), hal. 81

${ }^{2}$ Nur Ahid, Pendidikan Keluarga dalam Perspektif Islam, (Yogyakarta : Pustaka Persada, 2010), hlm.3.

${ }^{3}$ Nur Ahid, Pendidikan Keluarga dalam..., hlm. 75 dan 76.

${ }^{4}$ Asep Usmani Ismail, Menata Keluarga, Memperkuat Negara dan Bangsa Kiat Mewujudkan
Keluarga sebagai sistem sosial terkecil yang di dalamnya berlangsung proses pendidikan dan pengasuhan anak. Pola pengasuhan anak dalam keluarga mewarnai perkembangan kepribadian anak, bahkan menentukan sifat, sikap, karakter dan kecenderungan akhlak anak, baik akhlak terpuji maupun akhlak tercela. Proses pendidikan di dalam keluarga berlangsung secara almiah, mengikuti irama kehidupan, dan berlangsung setiap hari, bahkan setiap detik. Proses pendidikan di dalam keluarga sangat efektif, membekas pada jiwa anak, mempengaruhi kepribadian mereka.

Keluarga santri yang dimaksud dalam tulisan ini adalah sistem sosial terkecil yang terdiri dari bapak ibu dan anak, ${ }^{5}$ yang di dalamnya terjadi proses pembelajaran pendidikan agama Islam, yang bapak dan ibunya atau salah satu dari keduanya pernah mencari ilmu di pesantren, kemudian anak-anaknya di masukan ke pesantren atau madrasah diniyah yang berada di bawah lingkup pesantren, dengan harapan anak-anak tersebut mampu meneladani sifatsifat kenabian dan nilai-nilai keilahian tertanam dalam diri anak sebagaimana Rasulullah SAW ajarkan.

Permasalahan anak sekarang, baik di sekolah maupun di rumah umumnya kurang memiliki kesadaran pada persoalan aqidah, ibadah, dan akhlak. Anak-anak dengan mudah meninggalkan sholat dan membaca al Qur'an. Mereka suka berkumpul sambil merokok, kadang juga pesta miras dan bermain kartu hingga larut malam sampai lupa sholat fardhu, ${ }^{6}$ bahkan ada yang bergaul dengan teman sebayanya di luar batas kewajaran, akhirnya terjadi hal-hal yang tidak diharapkan oleh keluarga bahkan dirinya sendiri. ${ }^{7}$

Keluarga Sakinah, (Badan Litbang dan Diklat Kementrian Agama RI: Puslitbang Lektur dan Khasanah Keagamaan, 2011), hlm. 24-26.

${ }^{5}$ Hamid Darmadi, Pengantar Pendidikan Era Globalisasi: Konsep Dasar, Teori, Strategi, dan Implementasi dalam Pendidikan Globalisasi, (Banten :An1mage, 2019), hal 141

${ }^{6}$ Hasil observasi di desa Wonolelo pada tanggal 25-28 Maret 2018.

${ }^{7}$ Hasil wawancara dengan Bapak Khairil Anwar

LITERASI, Volume XI, No. $22020 \mid 105$ 
Anak-anak di Wonolelo rata-rata lahir dan berkembang dari pasangan suami istri yang salah satu atau keduanya adalah santri. Tujuan suami istri memilih pasangan hidup seorang santri, karena ingin membentuk keluarga santri. Selain itu mereka juga berharap pasangannya menjadi orang tua yang bisa mengajarkan ilmu-ilmu agama dan membaca al-Qur'an kepada anak-anaknya. ${ }^{8}$ Orang tua yang menyandang gelar santri di desa Wonolelo mempunyai tanggung jawab besar dan bukan perkara mudah. Mendidik seorang anak merupakan tantangan tersendiri bagi keluarga santri. Apalagi paradigma masyarakat Wonolelo predikat santri cukup menjadi sorotan dan teladan dalam beragama. Seorang santri berarti seorang yang mempunyai status sosial dan pengetahuan agama lebih. "Keluarga santri berarti keluarga yang siap menjadi sosrotan dan teladan dalam keberagamaan, berkeluarga, dan mendidik anak sebagaimana mestinya Islam ajarkan." 9

Tema keluarga santri menjadi permasalahan menarik untuk diteliti meskipun sudah ada bererapa penelitian tentang hal ini, misalnya penelitian Rafikasari Mutmainah dan Jumari, ${ }^{10}$ 2019, dengan judul "Metode Internalisasi Nilai-nilai Karakter dalam Keluarga Santri, Pedagang, dan Guru," yang mengkaji tentang nilai-nilai karakter yang ditanamkan dalam keluarga santri, pedagang, dan guru dan metode yang diterapkan untuk menginternalisasikan nilai-nilai karakter. Nur Hidayat dan Azzah Zayyinah, ${ }^{11}$ dengan judul

Efendi selaku kasi pelayanan di Desa Wonolelo dan Bapak Lutfi Amani selaku kepala padukuhan Dusun Ploso pada tanggal 28 Maret 2018.

${ }^{8}$ Wawancara pre reserch dengan Bapak Rizal, pada hari senin tanggal 15 Januari 2018

${ }^{9}$ Ibid.,

${ }^{10}$ Rafikasari Mutmainah dan Jumari, "Metode Internalisasi Nilai-nilai Karakter dalam Keluarga Santri, Pedagang, dan Guru", El-Islam Vol.1 Januari 2019

${ }^{11}$ Nur Hidayat dan Azzah Zayyinah, "Peran Ekstrakurikuler dalam Meningkatkan Karakter Santri Pondok Pesantren", Jurnal Literasi, Volume V, No. 1 Juni 2014, https://ejournal.almaata.ac.id/index.php/ LITERASI/article/view/405/320, 7 Desember 2020
"Peran Ekstrakurikuler dalam Meningkatkan Karakter Santri Pondok Pesantren", mengatakan bawah untuk meningkatkan karakter santri dibutuhkan beberapa kegiatan ekstrakurikuler, misalnya menjadi tim bina desa, kegiatan kaligrafi, tulis-menulis. Dalam pelaksanaan kegiatan ekstrakurikuler untuk meningkatkan karakter santri dipengaruhi beberapa faktor penghambat dan pendorong.

Lathifatul Izzah dan M. Hanip, ${ }^{12} 2018$ dengan judul "Implementasi Pendidikan Akhlak dalam Pembentukkan Akhlak Keseharian Santri Sunan Gunung Jati Gesing Kismantoro Wonogiri Jawa Tengah," mereka berusaha untuk mengungkap tentang implementasi pendidikan akhlak, sumber ajar dan bahan ajar, dan faktor pendukung dan penghambat pendidikan akhlak dalam pembentukan akhlak keseharian santri di pondok pesantren Sunan Gunung Jati Gesing Kismantoro Wonogiri Jawa Tengah.

Dari beberapa hasil penelitian tersebut di atas, penulis belum menemukan tulisan yang fokus pada persoalan proses dan implikasi implementasi pembelajaran pendidikan agama Islam dalam keluarga santri di desa Wonolelo kecamatan Pleret kabupaten Bantul, meskipun ada tulisan yang lebih mendekatinya, yaitu tulisan Rafikasari Mutmainah dan Jumari.

\section{METODE PENELITIAN}

Jenis penelitian ini adalah studi kasus dengan menggunakan metode kualitatif, metode penelitian yang menghasilkan data deskriptif analitis berupa kata-kata, tulisan atau lisan dari orang-orang yang perilakunya diamati. ${ }^{13}$ Kehadiran penulis sendiri sebagai instrumen penelitian dibantu dengan alat-alat perekam

${ }^{12}$ Lathifatul Izzah dan M. Hanip, “Implementasi Pendidikan Akhlak dalam Pembentukkan Akhlak Keseharian Santri Sunan Gunung Jati Gesing Kismantoro Wonogiri Jawa Tengah, Jurnal Literasi, Volume IX, No. 1, 2018, hal. 63., https://ejournal.almaata.ac.id/index. php/LITERASI/article/view/722/991, 7 Desember 2020,

${ }^{13}$ Lexy J. Moleong, Metodologi Penelitian Kualitatif, ( Bandung: Rosda Karya, 2002), hlm. 3, lihat juga Sugiono, Metode Penelitian Pendidikan, Pendekatan Kuantitatif, Kualitatif dan R\&D, ( Bandung: Alfabeta, 2014), hlm. 15. 
dan pencatat data untuk mengumpulkan data tentang implementasi pembelajaran pendidikan agama Islam dalam keluarga santri. Teknik pengumpulan data yang dipakai berupa observasi, wawancara, dan dokumentasi. Dalam pengamatan, peneliti terlibat secara aktif dan pasif. Secara pasif, peneliti tidak terlibat dalam kegiatan-kegiatan subyek penelitian dan tidak berinteraksi dengan subjek penelitian secara langsung. Sedang secara aktif, peneliti terlibat dalam kegiatan-kegiatan subyek penelitian dan berinteraksi secara langsung. ${ }^{14}$ Teknik ini dilakukan untuk memperoleh data tentang situasi, kondisi lingkungan keluarga santri di Desa Wonolelo Pleret. Keluarga santri yang dipilih sebagai subjek penelitian ini adalah keluarga santri yang memiliki anak usia sekolah menengah pertama, anak usia 12-21 tahun yang dipesantrenkan atau disekolahkan di madrasah diniyah lingkup pondok pesantren. ${ }^{15}$ Dalam hal ini terdapat 8 keluarga santri di Wonolelo yang memenuhi kriteria tersebut.

Di samping observasi, penulis juga memakai teknik wawancara mendalam (depth interview) untuk pengumpulan data, yaitu teknik untuk memahami persepsi, perasaan, dan pengetahuan orang-orang yang tahu dan terlibat tentang pembelajaran pendidikan agama Islam dalam keluarga Santri di Wonolelo. ${ }^{16}$ Dokumentasi juga dipakai dalam pengumpulan data yang bentuknya bisa berupa catatan, rekaman suara, dokumen yang berkaitan dengan subyek penelitian seperti jurnal, hard copy, dokumen-dokumen dan foto.

Data-data yang sudah terkumpul, kemudian diverifikasi dengan menggunakan teknik trianggulasi data, pemeriksaan keabsahan data yang memanfaatkan sesuatu yang lain di luar data untuk keperluan pengecekan atau sebagai pembanding terhadap data. ${ }^{17}$ Teknik trianggulasi

${ }^{14}$ M. Djunaidi Ghony dan Fauzan Al Manshur, Metodologi Penelitian Kualitatif, (Jogjakarta: Ar-Ruzz Media, 2012), hlm. 165.

${ }^{15}$ Hasil observasi yang dilakukan dari tanggal 01 Februari 2018.

${ }^{16}$ Ibid., 175.

${ }^{17}$ Lexy J. Moleong, Metodologi Pendidikan, data yang digunakan adalah trianggulasi sumber, yaitu membandingkan dan mengecek balik derajat kepercayaan yang diperoleh melalui waktu dan nilai yang berbeda dalam metode kualitatif yaitu dengan jalan: pertama, membandingkan data hasil pengamatan dengan data hasil wawancara. Kedua membandingkan apa yang dikatakan orang di depan umum dengan apa yang dikatakan secara pribadi. Ketiga, membandingkan keadaan dan perspektif seseorang dengan berbagai pendapat dan pandangan orang seperti rakyat biasa, orang yang berpendidikan menengah/tinggi, dan orang yang berada dalam pemerintah. Keempat, membandingkan hasil wawancara dengan isi suatu dokumen yang berkaitan.

Proses analisis data dimulai dengan menelaah seluruh sumber data yang tersedia dari berbagai sumber baik data dari observasi, wawancara, pengamatan yang sudah dituliskan dalam cacatan lapangan dilokasi penelitian, dokumen pribadi, dokumen resmi, gambar, foto, dan sebagainya. Analisis data pada penelitian kualitatif dilakukan melalui pengaturan data secara logis dan sistematis. Analisis data dilakukan sejak awal penelitian terjun ke lokasi penelitian hingga pada akhir penelitian (pengumpulan data). ${ }^{18}$ Setelah data diperoleh, kemudian disusun, dan diklasifikasikan sesuai katagori yang telah ditentukan. Teknik analisis yang digunakan adalah analisis induktif, yaitu suatu cara berpikir untuk menarik suatu kesimpulan yang bersifat umum dari berbagai kasus yang bersifat individual. ${ }^{19}$ Teknik ini digunakan untuk menganalisa data-data yang diperoleh di lapangan, kemudian dihubungkan dengan teori yang relevan untuk menarik kesimpulan.

\footnotetext{
Metodologi Penelitian Kualitatif, (Bandung: PT Remaja Rosdakarya, 2011), hlm. 330.

${ }^{18} \mathrm{M}$. Djunaidi Ghony dan Fauzan Al-Mansur, Metodologi Penelitian..., hlm. 246.

${ }^{19}$ Sutrisno Hadi, Metodologi Research, (Jogjakarta, Fak. Psikologi UGM, 1986), Hlm. 4.
} 


\section{HASIL DAN PEMBAHASAN}

Tulisan ini berusaha untuk mengungkap tentang bagaimana proses implementasi pembelajaran pendidikan agama Islam dalam keluarga santri, studi kasus di desa Wonolelo Pleret Bantul? Dan bagaimana implikasi implementasi pembelajaran pendidikan agama Islam dalam keluarga santri studi kasus di Wonolelo Pleret Bantul?

\section{Proses Implementasi Pembelajaran Pendidikan Agama Islam di Keluarga Santri}

Proses implementasi pembelajaraan bisa efektif diperlukan perencanaan, pelaksanaan, dan evaluasi sebagaimana yang diungkap oleh Robert H. Davis dan Castteter yang dikutip oleh Jejen Musfah. ${ }^{20}$ Hal ini juga terjadi dalam proses implementasi pembelajaran pendidikan agama Islam dalam keluarga santri, yang secara tidak langsung orang tua yang berperan sebagai pendidik membuat perencanaan. Sebagian besar keluarga santri beranggapan, sebelum melakukan segala sesuatu penting membuat perencanaan dan tujuan yang jelas. ${ }^{21}$ Sebelum membangun keluarga, mereka terlebih dahulu menuntut ilmu agama dan mendalami al Qur'an di pesantren-pesantren sebagai bekal kehidupan di masa depan. Salah satunya membangun keluarga SAMARAMAS (Sakinah Mawadah Rahmah Maslahah). Mereka sabar, memiliki bekal yang cukup, mengikuti petunjuk para kiai atau guru, dan tidak sedikit waktu yang dibutuhkan untuk menuntut ilmu, sebagaimana yang dipesankan Ali bin Abi Thalib karramallahu wajhah bahwa syarat yang penting untuk diperhatikan oleh peserta didik untuk mendapatkan ilmu yang bermafaat, yaitu cerdas, penuh harap (optimisme), shabar, berbekal, mengikuti petunjuk guru, dan memiliki waktu yang

${ }^{20}$ Jejen Musfah, Peningkatan Kompetensi Guru Melalui Pelatihan dan Sumber Belajar Teori dan Praktik, Cet. Ke-2, (Jakarta: Kencana, 2012), hal. 97-98.

${ }^{21}$ Wawancara dengan Bapak Akhmat Farid selaku tokoh masyarakat desa Wonolelo pada tanggal 20 April 2018 jam 19.00 WIB cukup. ${ }^{22}$ Bekal yang cukup tidak semata-mata harta benda, bisa berupa tekat yang kuat, mau prihatin (usaha dzahir dan batin yang kuat). Mereka sabar dengan yang subhat (tidak jelas halal haramnya), lebih-lebih yang haram.

Mereka memilih puasa untuk menghindari baik makanan subhat ataupun haram. Makanan akan menjadi darah dan daging. Darah akan mengalir ke tubuh anak yang dilahirkan nanti. Jika darah yang dialirkan dari makanan subhat atau haram, bagaimana mungkin harapan atau tujuan memiliki keluarga sakina mawadah wa rahmah, maslahah terkabul, memiliki putraputri yang berbakti, ahli ilmu dan kebaikan, serta shaleh shaleha tercapai. Begitu juga dengan waktu yang mereka butuhkan, mereka tidak boyong (kembali ke rumah) sebelum apa yang menjadi tujuan awal dalam menuntut ilmu diperoleh, misalnya dalam menghafal al Qur'an, sebelum hafal 30 juz mereka tidak akan pulang, mereka tidak boyong sebelum lulus dalam menuntut ilmu. ${ }^{23}$

Keluarga santri dalam merencanakan pembelajaran pendidikan agama Islam juga merencanakan sebelum menjalani kehidupan berkeluarga. Materi-materi yang mereka persiapkan otomatis materi-materi yang mereka dapat dari pesantren, baik berupa materi tentang aqidah, ibadah, maupun akhlak. ${ }^{24}$ Sehingga dalam pelaksanaannya atau ketika mereka berkeluarga mereka mengajarkan materi-materi tersebut, baik melalui metode pembiasaan, kisah / cerita, keteladanan, hafalan, ajakan (diperintah sambil diberi bimbingan dan contoh), reward, punishment, bernyanyi, cerita, dan pendampingan. Mereka mengikuti apa yang diteladankan Rasulullah SAW: pada umur 0-7

${ }^{22}$ Juwariyah, "Pengertian dan Komponenkomponen Pendidikan Islam Perspektif Mahmud Yunus dan Muhammad 'Athiyah al Abrasyi (Tinjauan Analisis Kritis)”, jurnal Muqadimmah, Vol. XV, No. 26. Januari - Juni 2009, hlm. 79- 80

${ }^{23}$ Wawancara dengan Ibu Habibah pada tanggal 17 April 2018 pada pukul 20.00 WIB dan 23 April 2018 pada pukul 17.00 WIB.

${ }^{24}$ Wawancara dengan Ibu Nurul Islamiyah selaku ustadzah di desa Wonolelo pada tanggal 14 April 2018 pada pukul 17.00 WIB 
tahun anak diibaratkan raja apa yang dia mau dikasih, tetapi ketika menginjak usia 7-14 tahun, anak bagaikan tahanan penjara. Pada saat anak berumur 7-14 tahun, orang tua mulai memberi penekanan-penekanan yang bersifat positif, sehingga ketika menginjak usia 15-21 tahun karakternya sudah terbentuk. Seperti pepatah orang jawa "dugang bujang semon camat esem bupati" (jika usia anak-anak ketika ada pekerjaan atau sesuatu harus disuruh, jika usia remaja jika ada pekerjaan atau sesuatu hanya dengan sindiran, dan jika dewasa cukup dengan senyuman). ${ }^{25}$

Keluarga santri mengajarkan materimateri aqidah meliputi keyakinannya kepada Allah, qadha dan qadar (ketentuan Allah SWT yang baik dan buruk). Mislanya dalam hal rizki mereka disamping berusaha sekuat tenaga, juga memasrahkan kepada Allah SWT, Allah SWT sudah mengatur rizki makhluknya. ${ }^{26}$ Dalam hal keyakinannya kepada kitab Allah, pembelajaran al Qur'an menjadi materi prioritas dalam keluarga santri. Mereka tidak hanya menekankan untuk bisa membaca dan menghafal al Qur'an, mereka juga menganjurkan untuk mengamalkan isi kandungan al Qur'an. Dalam hal keimanannya kepada para nabi dan rasul Allah pembelajaran dilakukan melalui cerita dan bernyanyi dengan harapan putra-putrinya dapat meneladani sifat-sifat para nabi dan rasul. Begitu juga dengan dalam pembelajaran dalam menanamkan aqidah atau kepercayaannya kepada malaikat dan hari akhir, keluarga santri banyak memberi cerita-cerita.

Keyakinan atau keimanan tidak cukup hanya diajarkan, dipelajari dan diyakini di dalam hati dan pikiran, tetapi perlu juga diucapkan dengan lisan dan diamalkan dengan perbuatan. Keluarga santri juga selalu menanamkan aqidah sejak mereka dalam kandungan dan baru lahir. Sejak dalam kandungan senandung muratal

\footnotetext{
${ }^{25}$ Wawancara dengan Bapak Akhmat Farid selaku tokoh masyarakat desa Wonolelo pada tanggal 6 April 2018 jam 19.30 WIB

${ }^{26}$ Wawancara dengan Bapak Komar selaku tokoh masyarakat desa Wonolelo pada tanggal 5 April 2018 jam 17.00 WIB
}

al Qur'an 30 juz dan lantunan shalawat nabi sudah seringkali disenandungkan. Setiap hari bapak ibunya membacakan surat al Qur'an, terutama surat Maryam dan Yusuf. Adzan dikumandangkan di telinga kanan dan iqamah diperdengarkan di telinga kiri, ketika putrapurinya sehabis dibersihkan dari baluran darah ibunya sehabis dilahirkan. ${ }^{27}$ Tidak cukup itu dalam mematrikan aqidah, ibadah dan akhlak, kelurga santri juga menanamkan melalui nama. Mereka memberi nama putra-putrinya nama-nama nabi dan ulama atau tokoh besar, serta asmaul husna dengan harapan dapat meneladaninya. Sebelum putra-putrinya belum mencari nafkah sendiri, orang tuanya sering kali mengadakan syukuran dan selamatan (do'a bersama dan sedekah) untuk putra-putrinya, dengan harapan anaknya selamat dunia akhirat, menjadi anak sholeh sholehah, berbakti, dan bermanfaat.

Dalam bidang Syari'ah atau ibadah, pada saat putra-putrinya sudah mulai bisa berbicara, anggota keluarga santri sudah mulai mengajarkan dua kalimat syahadat, mengajarkan dzikir, shalawat, dan sejenisnya. Sudah mulai bisa belajar membaca dan menulis, anak-anak mereka sudah diajarkan niat, do'a, dan bacaan bersuci atau wudhu dan sholat, serta do'a sehari-hari. ${ }^{28}$ Sudah mulai kuat menahan lapar mereka sudah mengajarkan anak-anaknya berpuasa wajib, mulai diajak makan sahur walaupun kadang anak-anak mereka jam 10.00 atau dzuhur atau asar sebelum waktu berbuka (Maghrib) mereka sudah tidak kuat (minta makan dan minum). Setelah mulai usia baligh atau remaja awal, putra-putri mereka sudah diajak puasa sunah, pada umumnya mereka diajak puasa sunnah Senin dan Kamis. ${ }^{29}$ Dalam

${ }^{27}$ Observasi dan wawancara dengan Wawancara dengan Ibu Sulthonah pada tanggal 20 April 2018 jam 20.00 WIB

${ }^{28}$ Wawancara dengan Ibu Nurul Islamiyah selaku ustadzah di desa Wonolelo pada tanggal 5 April 2018 pada pukul 17.00 WIB

${ }^{29}$ Wawancara dengan Ibu Sulthonah selaku pengasuh pondok pesantren pada tanggal 11 April 2018 pukul 19.00 WIB 
hal ibadah keluarga santri pada umumnya lebih banyak menekankan pada membaca bahkan menghafal al Qur'an, puasa termasuk puasa sunnah Senin Kamis, menjaga shalat dan melestarikan atau membiasakan sholat berjama'ah, mengajarkan dan mengamalkan al Qur'an, puasa, shadaqah atau berbagi. ${ }^{30}$

Dalam hal akhlak baik pada diri sendiri, Allah, lingkungan, dan makhluk lainnya, keluarga santri senantiasa menanamkan hormat, tidak menyakiti sesama manusia, menyayangi semua makhluk, rendah hati, berlaku sopan, ikhlas, membahagiakan orang, istiqamah, ketenangan dan kebahagiaan hidup baik di dunia atau akhirat, kesungguhan, tanggung jawab, berbicara yang baik, disiplin, peduli sosial, tegas, saling menghargai, berperilaku adil, sederhana, ramah, hati-hati dalam hal ibadah, syukur, menjaga silaturahmi, sederhana, kasih sayang, berbuat baik dan tidak merugikan orang lain, peduli sosial, mawas diri atau hati-hati, berbuat baik tanpa membedakan latar belakang, tidak sombong, konsisten atau istiqomah, menghormati orang tua dan guru, optimis, berkemauan keras, usaha, dan tawakal.

Dalam lingkungan pergaulan, keluarga santri juga sangat memperhatikan. Di samping metode dan materi, lingkungan positif juga mempengaruhi keberhasilan dalam pendidikan anak. ${ }^{31}$ Lingkungan dan kecanggihan teknologi dapat mempengaruhi gagal dan suksesnya pembelajaran dalam keluarga. Selain itu ada juga faktor penting lainnya untuk kesuksesan pendidikan keluarga, yaitu kekompakan (kerjasama yang baik) dari anggota keluarga, termasuk kedua orang tua. ${ }^{32}$

Evaluasi juga menjadi bagian penting dalam pendidikan keluarga santri. Evaluasi biasanya dilakukan secara tidak langsung.

\footnotetext{
${ }^{30}$ Wawancara dengan Bapak Akhmat Farid selaku tokoh masyarakat desa Wonolelo pada tanggal 20 April 2018 jam 19.00 WIB

${ }^{31}$ Wawancara dengan Ibu Robaniyah pada tanggal 19 April 2018 pada pukul 15.00 WIB

${ }^{32}$ Wawancara dengan Bapak Akhmat Farid selaku tokoh masyarakat desa Wonolelo pada tanggal 11 April 2018 jam 19.00 WIB
}

Umumnya evaluasi dilakukan saat makan, membantu pekerjaan rumah, nonton TV, jalanjalan, dan hari raya Idul Fitri. Pada saat nonton TV, jalan-jalan, dan makan kadang anak-anak cerita dan orang tua juga terkadang membuka pertanyaan agar anak bercerita tentang kegiatan sehari-harinya, di situlah ada dialog yang akrab, mengevalasi, dan memberi nasihat perbaikan antar anggota keluarga. Pada saat hari Raya, sehabis shalat Id, anak-anak biasanya melakukan "sungkem" pada kedua orang tuanya dan saling memaafkan..$^{33}$

Pada sejatinya peserta didik dan pendidik dalam pendidikan keluarga santri adalah semua anggota keluarga, tidak selamanya orang tua menjadi pendidik dan tidak selamanya anak atau yang muda menjadi peserta didik. Meskipun seringkali dalam pendidikan keluarga santri orang tua berperan sebagai pendidik dan anakanak atau yang muda menjadi peserta didik. ${ }^{34}$

\section{Implikasi Implementasi Pembelajaran Pendidikan Agama Islam dalam Keluarga Santri}

Implikasi implementasi pembelajaran pendidikan agama Islam pada keluarga santri adalah pertama, tertanamnya ajaran-ajaran Islam baik terkait aqidah, ibadah dan akhlak secara efektif dan efisen. Anggota keluarga, termasuk anak yang berperan sebagai peserta didik memiliki karakter yang baik, baik selaku menjadi diri sendiri, berhubungan Allah, Tuhan Alam Semesta dan makhluk lainnya. Contoh karakter yang tertanam selaku menjadi diri pribadi, mereka memiliki karakter hatihati dan mawas diri, disiplin, sederhana, berkemauan dan usaha keras, optimis, tawakal, tidak sombong, konsisten atau istiqomah, mengutamakan ketenangan dan kebahagiaan hidup dunia akhirat, sungguh-sungguh, dan tegas. Karakter berhubungan dengan Allah Tuhan Alam Semesta, religius, hati-hati dalam hal ibadah, syukur, dan ikhlas. Terakhir karakter

${ }^{33}$ Observasi di 8 keluarga santri desa Wonolelo Pleret Bantul Yogyakarta Januari - April 2018

${ }^{34}$ Observasi di 8 keluarga santri desa Wonolelo Pleret Bantul Yogyakarta Desember 2017 - April 2018 
yang dimiliki keluarga santri berkaitan dengan makhluk dan sesama manusia: hormat dan menghargai, tidak menyakiti sesama manusia, menyayangi semua makhluk, rendah hati, berlaku sopan, membahagiakan orang, tanggung jawab, berbicara baik, peduli sosial, adil, ramah, menjaga silaturahmi, kasih sayang, berbuat baik dan tidak merugikan orang lain, dan berbuat baik tanpa membedakan latar belakang.

\section{KESIMPULAN}

Hasil penelitian tentang implementasi pendidikan agama Islam dalam keluarga santri yang sudah diuraikan dapat disimpulkan sebagai berikut: proses implementasi pembelajaran pendidikan Agama Islam dalam keluarga santri dapat dilakukan melalui proses perencanaan, pelaksanaan dan evaluasi. Proses implementasi pembelajaran pendidikan agama Islam dalam keluarga santri dapat berhasil dengan baik karena didukung oleh berbagai macam faktor. Diantaranya adalah materi, metode, lingkungan, teknologi, dan kerjasama atau kekompakan antar anggota keluarga, terutama kedua orang tua. Akhirnya pendidikan keluarga dapat berdampak atau berimplikasi pada karakter anggota keluarga, terutama anak selaku menjadi diri sendiri, berhubungan pada Allah Tuhan Alam Semesta, makhluk sesama makhluk Allah,

\section{DAFTAR PUSTAKA}

Asep Usmani Ismail, Menata Keluarga, Memperkuat Negara dan Bangsa Kiat Mewujudkan Keluarga Sakinah,Badan Litbang dan Diklat Kementrian Agama RI: Puslitbang Lektur dan Khasanah Keagamaan, 2011.

Hamid Darmadi, Pengantar Pendidikan Era Globalisasi: Konsep Dasar, Teori, Strategi, dan Implementasi dalam Pendidikan Globalisasi, Banten :An1mage, 2019.

Hasil wawancara dengan Bapak Khairil Anwar Efendi selaku kasi pelayanan di Desa Wonolelo dan Bapak Lutfi Amani selaku kepala padukuhan Dusun Ploso pada tanggal 28 Maret 2018.
Imam Machalli, "Pendekatan IntegratifInterkonektif dalam Kajian Kebijakan dan Manajemen Pendidikan Islam", dalam M. Amin Abdullah, dkk. Implementasi Pendekatan Integratif-Interkonektif dalam Kajian Pendidikan Islam, (Yogyakarta: Pascasarjana UIN Sunan Kalijaga, 2014

Jejen Musfah, Peningkatan Kompetensi Guru Melalui Pelatihan dan Sumber Belajar Teori dan Praktik, Cet. Ke-2, Jakarta: Kencana, 2012.

Juwariyah, "Pengertian dan Komponenkomponen Pendidikan Islam Perspektif Mahmud Yunus dan Muhammad 'Athiyah al Abrasyi (Tinjauan Analisis Kritis)", jurnal Muqadimmah, Vol. XV, No. 26. Januari - Juni 2009

Lathifatul Izzah dan M. Hanip, "Implementasi Pendidikan Akhlak dalam Pembentukkan Akhlak Keseharian Santri Sunan Gunung Jati Gesing Kismantoro Wonogiri Jawa Tengah, Jurnal Literasi, Volume IX, No. 1, 2018, hal. 63., https://ejournal. almaata.ac.id/index.php/LITERASI/ article/view/722/991, 7 Desember 2020,

Lexy J. Moleong, Metodologi Pendidikan, Metodologi Penelitian Kualitatif, Bandung: PT Remaja Rosdakarya, 2011. -------, Metodologi Penelitian Kualitatif, ( Bandung: Rosda Karya, 2002), hlm. 3, lihat juga Sugiono, Metode Penelitian Pendidikan, Pendekatan Kuantitatif, Kualitatif dan R\&D, Bandung: Alfabeta, 2014.

M. Djunaidi Ghony dan Fauzan Al Manshur, Metodologi Penelitian Kualitatif, Yogjakarta: Ar-Ruzz Media, 2012.

Nur Ahid, Pendidikan Keluarga dalam Perspektif Islam, Yogyakarta : Pustaka Persada, 2010.

Nur Hidayat dan Azzah Zayyinah, "Peran Ekstrakurikuler dalam Meningkatkan Karakter Santri Pondok Pesantren", Jurnal Literasi, Volume V, No. 1 Juni 2014, https://ejournal.almaata.ac.id/index. php/LITERASI/article/view/405/320, 7 Desember 2020

LITERASI, Volume XI, No. 2 2020 111 
Rafikasari Mutmainah dan Jumari,"Metode Internalisasi Nilai-nilai Karakter dalam Keluarga Santri, Pedagang, dan Guru", El-Islam Vol.1 Januari 2019

Sutrisno Hadi, Metodologi Research, Yogjakarta, Fak. Psikologi UGM, 1986

\section{Observasi dan Wawancara:}

Observasi dan wawancara dengan Wawancara dengan Ibu Sulthonah pada tanggal 20 April 2018 jam 20.00 WIB

Observasi di 8 keluarga santri desa Wonolelo Pleret Bantul Yogyakarta Januari - April 2018

Observasi di 8 keluarga santri desa Wonolelo Pleret Bantul Yogyakarta Desember 2017 - April 2018

Observasi di desa Wonolelo pada tanggal 25-28 Maret 2018.

Observasi yang dilakukan dari tanggal 01 Februari 2018.

Wawancara dengan Bapak Akhmat Farid selaku tokoh masyarakat desa Wonolelo pada tanggal 20 April 2018 jam 19.00 WIB

Wawancara dengan Bapak Akhmat Farid selaku tokoh masyarakat desa Wonolelo pada tanggal 6 April 2018 jam 19.30 WIB
Wawancara dengan Bapak Akhmat Farid selaku tokoh masyarakat desa Wonolelo pada tanggal 20 April 2018 jam 19.00 WIB

Wawancara dengan Bapak Akhmat Farid selaku tokoh masyarakat desa Wonolelo pada tanggal 11 April 2018 jam 19.00 WIB

Wawancara dengan Bapak Komar selaku tokoh masyarakat desa Wonolelo pada tanggal 5 April 2018 jam 17.00 WIB

Wawancara dengan Ibu Habibah pada tanggal 17 April 2018 pada pukul 20.00 WIB dan 23 April 2018 pada pukul 17.00 WIB.

Wawancara dengan Ibu Nurul Islamiyah selaku ustadzah di desa Wonolelo pada tanggal 14 April 2018 pada pukul 17.00 WIB

Wawancara dengan Ibu Nurul Islamiyah selaku ustadzah di desa Wonolelo pada tanggal 5 April 2018 pada pukul $17.00 \mathrm{WIB}$

Wawancara dengan Ibu Robaniyah pada tanggal 19 April 2018 pada pukul 15.00 WIB

Wawancara dengan Ibu Sulthonah selaku pengasuh pondok pesantren pada tanggal 11 April 2018 pukul 19.00 WIB

Wawancara pre reserch dengan Bapak Rizal, pada hari senin tanggal 15 Januari 2018 